\title{
The Impersonal Is Political: Spinoza and a Feminist Politics of Imperceptibility
}

\author{
HASANA SHARP
}

This essay examines Elizabeth Grosz's provocative claim that feminist and anti-racist theorists should reject a politics of recognition in favor of "a politics of imperceptibility." She criticizes any humanist politics centered upon a dialectic between self and other. I turn to Spinoza to develop and explore her alternative proposal. I claim that Spinoza offers resources for her promising politics of corporeality, proximity, power, and connection that includes all of nature, which feminists should explore.

In several places throughout her writings, Elizabeth Grosz urges feminist and post-colonial theorists to think beyond the "regime of recognition," which, she contends, cannot escape an investment in a humanistic politics of identity (Grosz 2002, 2005). Rather than mobilize for visibility, intersubjective affirmation, and cross-cultural and mutual understanding, she advocates "a politics of imperceptibility" grounded in an inhuman ontology of forces. In this paper, I will outline some of the problems Grosz identifies with a politics of recognition and explore her somewhat surprising exhortation to "imperceptibility" and "impersonality." I propose that Grosz's idiom of force, nature, and impersonality is grounded in an effort to produce a political vocabulary entirely alien to humanism. I understand humanism in politics to include any vision of justice that is grounded in a special feature of existence that is not exhibited by non-human beings but is held to be universally shared by humans. Thus, any politics grounded in the recognition of shared rationality, the universal ability to formulate one's life plan or vision of the good, or the capacity to assume reciprocal obligations would be included. Grosz is not concerned, however, with any and all political theory, but specifically with feminist and anti-racist thought. A number of feminist and anti-racist theorists have often found the politics of recognition to be more congenial than either liberal individualism, which disavows the constitutive role of relationships and radical human dependency in shaping autonomy and selfhood (see, for example, Kittay 1998), or an unmodified communitarianism, which lacks a sufficient analysis of power relationships internal to communities (Frazer and Lacey 1993). Many feminists have been attracted to the emphasis in the politics of recognition 
upon the arduous and delicate intersubjective processes of establishing relationships of respect, equality, and sympathy among people with distinct languages, cultures, histories, and perspectives. Likewise, such theorists appreciate that the politics of recognition treats the profound damage that can be caused by oppressive socio-symbolic regimes, which cannot be captured by a theory that focuses exclusively on the just distribution of goods, or on the rights owed to individuals. Without dismissing the genuine concerns of these feminist and anti-racist thinkers, Grosz rejects the politics of recognition on the grounds that the desire to be known, seen, and valued by the other is an inevitably submissive acquiescence to a humanism that can never fail to be masculine.

In an effort to imagine what her alternative "politics of imperceptibility" might entail, 1 turn to Spinoza's critique of anthropocentrism as a disabling feature of human imagination. In support of Grosz's suggestive remarks, Spinoza's philosophy reveals how a non-humanist theory might actually better address some of the needs identified by a politics of recognition. In particular, I offer an interpretation of Spinoza's philosophy precisely as a remedy for the genuine psychic and corporeal damage provoked by, for example, misogyny and cultural imperialism, to which the politics of recognition rightly aims to respond. Spinoza's alternative, moreover, intersects with Grosz's call for a positive and experimental politics animated by a desire for joyful affects and the enhancement of bodily pleasures, practices, and powers. I aim to show both that Spinoza's philosophy offers an alternative analysis and remedy for the sad affects that are traditionally understood to follow from misrecognition and that it generates alternative affective criteria for measuring the successes and failures of political practice. While I do not argue that Spinoza's politics are equivalent to Grosz's politics of imperceptibility, I outline how Spinoza's thought offers further resources for the development of a promising politics of corporeality, proximity, and connection beyond and in excess of the human.

\section{The Politics of ReCOGNition}

The politics of recognition has come under suspicion by several thinkers recently (Oliver 2001; Markell 2003), even as it arguably remains a predominant way of conceiving political struggle in North American and western European multicultural democracies. No doubt, many are familiar with the debates about whether the terrain of politics has shifted entirely toward recognition and away from redistribution (Fraser 1995), but the various parties generally concede Charles Taylor's claim that recognition comprises "a vital human need" and that the misrecognition of identities is an appropriate way of understanding oppression and injustice in late capitalism. Present-day theories of recognition are diverse and often vague as to what precisely the desire for recognition is, what aspect of the self or group requires and is owed recognition, by whom, and toward what end. Moreover, as Patchen Markell has pointed 
out, it is often unclear whether the politics of recognition aims to recognize the already existing truths of intact identities, or whether the dynamics of recognition are meant to bring into being and enable the very subjectivities (identities) to whom recognition is due. In other words, Markell asks whether the politics of recognition is meant to know or to make social subjects (Markell $2000,496)$. Of course, the Hegelian paradigm allows doing and knowing to be understood as dynamic, co-constitutive processes, yet the metaphysical and epistemological tension between becoming and recognizing may suggest that the satisfaction of a desire for recognition is an awkward yardstick for justice. In other words, if the construction of individual and group identity is an ongoing, responsive, and intersubjective process, how can moral demands for recognition be completed?

Although many ambiguities remain constitutive of a politics of recognition, one can nevertheless identify its fundamental animating principles. Most basically, theories of recognition aim to replace the monadic model of liberal individualism with a dyadic or intersubjective model of social subjectivity derived from Hegel's famous master-slave dialectic. Theorists in this neo-Hegelian tradition aim to construct moral and political theories that treat freedom as an achievement that depends upon social relationships and institutional conditions conducive to the development of "an intact identity" and a positive relationship to oneself (Honneth and Fraser 2003). Moreover, the framework of recognition develops a radically social understanding of human psychology, which entails attention to the less measurable forms of injustice inflicted by, for example, pervasive symbolic depreciation of particular social identities. That is, the politics of recognition takes account of how systematic social invisibility, misrepresentation, or distortion constitute a genuine harm-indeed, in extreme cases, psychic mutilation-to the autonomy of individuals and groups. As most theorists would be willing to acknowledge, the damage produced by histories of conquest, genocide, slavery, colonialism, cultural and linguistic imperialism, and millennia of patriarchy is not healed by formal equality, greater access to jobs, housing, and social services alone. In the words of Charles Taylor, "misrecognition shows not just a lack of due respect. It can inflict a grievous wound, saddling its victims with crippling self-hatred. Due recognition is not just a courtesy we owe people. It is a vital human need" (Taylor 1992, 26). Whether and how this vital need is met through political practice and institutions animates many debates and divisions within political thought today.

It is far beyond the scope of this paper and Elizabeth Grosz's project to address these debates as a whole. Grosz addresses her critique of recognition and her exhortation to think otherwise specifically to feminist and post-colonial thinkers. Thus, she targets those who write as or on behalf of the oppressed and misrecognized, those who may be, according to Taylor, enduring "grievous wound[s]" and suffering "crippling self-hatred." In particular, Grosz responds to 
an essay co-authored by Drucilla Cornell and Sara Murphy as well as to the influential work of Judith Butler, whose recent writings frequently invoke a political understanding of recognition. Grosz clearly engages these particular theorists by virtue of sympathy for their overall political impulses and a shared desire to fight racism and sexism. Yet she urges those who understand themselves to be either misrecognized, or writing on behalf of the misrecognized, to reject both the model of recognition and the intersubjective dynamic it presupposes. She makes what may be a startling suggestion that feminists and post-colonial thinkers forget about "the Other" and affirm the irrepressibly agonistic dynamics of nature and bodily forces. It is to her suggestive critique that I now turn.

\section{Grosz's Critique of the Politics of Recognition}

Grosz's call for a politics of imperceptibility first appears in a critical response to an essay by Cornell and Murphy, "Anti-racism, Multiculturalism, and an Ethics of Identification" (Cornell and Murphy 2002). In her response, Grosz applauds Cornell and Murphy for endeavoring to re-formulate a politics of recognition that is not tied to the acknowledgment of an authentic, prepolitical, conscious cultural identity, which is a model they attribute to Charles Taylor. Cornell and Murphy aim to decouple the struggle for recognition from any notion of "authenticity," while advocating an "ethics of identificarion." The notion of authenticity derived from Herder and Trilling presupposes that we are all equally human, but each in our own irreducibly unique way. Even as Taylor, with Hegel, insists that we become who we truly are, in our singularity, only by virtue of our relationships with others, Cornell and Murphy contend that the affirmation of others as "authentic" entails an unacceptably static notion of personal and cultural identity $(420,444)$. Moreover, authenticity risks the eclipse of the need to recognize individuals as the sources of the meanings of their identities, meanings that are continually being revised and reinterpreted (421). Instead, they advocate an "ethics of identification," which implies an ongoing transformative practice among diverse social actors and allows for the emergence of incipient, novel identities. They claim that emphasis should be placed upon the freedom to recreate oneself through the assertion and recognition of one another's humanity. The basis of such a politics should be the dignity and respect owed to all human beings, which entails attention to each person's potential and need to develop and transform her self-representation and cultural meaning. Cornell and Murphy advocate the (state) provision of "the psychic and moral space" in which the oppressed are as able as anyone else to intervene in and shape how they are seen through participation in public discourse, art, and literature. ${ }^{1}$

Although Grosz appreciates the move away from a narrow politics of identity conceived in terms of authenticity, in which the oppressed struggle to be seen for who they really are, she remains highly critical of any language 
of recognition. Ultimately, she fears that any vision of justice predicated upon the validation of social subjects by other subjects belongs to "a politics that is fundamentally servile." Grosz acknowledges that minorities seek recognition from each other and not necessarily from the dominant culture, but she advocates a far more radical rejection of any conception of the self that is "governed, in advance, by the image and value of the other," no matter who that other happens to be (Grosz 2002, 471). In a different discussion of the same essay, Grosz advocates a turn to a Nietzschean conception of the subject precisely because it is wholly "indifferent to the other" (Grosz 2005, 86). She urges her readers to think instead about politics in terms of agonistic forces, impersonal and trans-human becomings, and unmasterable and uncognizable struggle (Grosz 2002, 469). She calls for the politics of recognition and identity to be supplanted by a fight for "bodily activities and practices" (Grosz 2005, 87).

Needless to say, Grosz's is far from a typical feminist critique of Hegelian and neo-Hegelian theories of intersubjectivity and recognition. Kelly Oliver, for example, endeavors to go "beyond recognition" on the grounds that subjectivity need not be considered in terms of violence and antagonism, as it is in Hegel, Sartre, or Butler (Oliver 2001). Oliver objects to a flattening account of any and all social subjectivity on the model of trauma and a portrait of all otherness in the image of threat and hostility. She argues, persuasively in my view, that such a universal account elides the real differences between coming to be a social subject under conditions of radical oppression and coming to be a subject in a context of privilege. Oliver endeavors to construct an alternative account of collective and dyadic intersubjectivity that neither presupposes violence nor covers over distinctively oppressive histories. Thus, her theory aims to respond and bear witness to the profound sufferings of particular others. At the same time, Oliver's theory supports the feminist vision of a just world in which social subjects might come to be in a context of responsiveness, attentive connection, and love.

Like Oliver, the vast majority of feminist theorists remain focused on ethical practices of attuning oneself better to others, especially the disadvantaged. They tend to promote political strategies that modify and refine symbolic representation, social meaning, and communicative interaction. For example, Oliver advocates an alternative notion of vision in terms of sensual connectivity, counter to the speculative tradition in the history of philosophy. Without revising the very notion of visual apprehension, Cornell and Murphy insist upon the right to participate actively in one's own social representations. In one way or another, a number of feminist theorists advocate seeing better, conceiving others more appropriately, and becoming better able to perceive differences in subjective experiences (compare Alcoff 2005). At the same time, many acknowledge in a Levinasian vein that an ideal of mutual transparency is neither possible nor desirable. Yet one is still called upon to become ever more critical, ever more sensitive to one's failure to see, conceive, or grasp the needs, 
desires, and experiences of other subjects. Even as a traditional model of transparent, mutual recognition is soundly rejected, ${ }^{2}$ the desire to see, perceive, and imagine better remains an animating ethical and political impulse in feminist and anti-racist theory.

Grosz, in stark contrast, does not advocate a theory of social subjectivity that is either less agonistic or more responsive to particular others and their histories. Her Nietzschean paradigm of impersonal, a-subjective forces renders violence and conflict both necessary and irresolvable. Grosz advocates a politics of imperceptibility precisely because it privileges acts, forces, energies, and bodies. Such a paradigm utterly rejects a dialectic of self and other, since, she notes, "acts don't have an 'other.' Only Subjects have an 'other" (Found Objects Collective, 2007, 4). In advocating imperceptibility, she clearly opposes a project of mutual clarification and disclosure. Rather, she urges her readers to join her in a political project that embraces opacity, dissolution, indiscernibility, and de-particularization.

What motivates Grosz's somewhat strange exhortation to imperceptibility? To whom might it be attractive? When one examines her inspiration for a politics of imperceptibility, her counter-program might appear even more perplexing. Grosz appropriates the notion of imperceptibility (without citation) from Deleuze's and Guattari's A Thousand Plateaus. The notion of becoming-imperceptible appears at the extreme end of a spectrum of "becoming-animal." Deleuze and Guattari propose becoming-animal as a notion of becoming that is not predicated on identification, imitation, resemblance, or analogy. Rather than the reflection of an unconscious urge to work out a psychic identification with a lost other-be it a parent, love-object, or part of oneself-becomings-animal are impersonal and unmasterable communications among and between bodily forces that cannot be represented by concepts or explained through developmental narratives. If I represent myself as feeling "like a banana slug," it may be the way I contain and imagine the destabilizing effect of a molecular exchange between the porous and dynamic assemblage I call "my body" and that of the myriad inhuman bodies upon which I depend and with which I cannot but coexist. Becomings-animal, according to Deleuze and Guattari, occur on a continuum that begins, on the one side, with what they call the "special introductory power" of becoming. woman and culminates, "at the far side," in becoming-imperceptible (1987, 248).

In an earlier work, Grosz assesses the conceptual apparatus of A Thousand Plateaus and finds precisely Deleuze and Guattari's affirmation of becomingwoman as a portal to becoming-imperceptible to be distasteful.

But there must remain a wariness, insofar as they too sever becoming-woman from being-woman, and make the specificities of becoming-woman crucial to men's quest for selfexpansion. They render women's becomings, their subversions, 
their minoritarian and marginal struggles subordinate to a cosmic becoming-imperceptible which amounts, in effect, to a political obliteration or marginalization of women's struggles. (Grosz 1993, 179)

Today, however, she urges precisely feminists and post-colonial theorists to embrace what once appeared to her as a mystical "obliteration" of the demands, desires, and projects of women. Perhaps the link between becoming-imperceptible and becoming-woman as part of the project of becominganimal is what prevents Grosz from noting that a politics of imperceptibility is conceptually inherited from Deleuze and Guattari. Yet insofar as the project of becoming-animal, -woman, -child, and -imperceptible belongs to a program of radical anti-humanism in Deleuze and Guattari, its lineage is essential to her critiques of Comell and Murphy as well as of Butler.

Cornell and Murphy preserve the language of recognition in part to affirm the necessity of contesting and opening up the symbolic content of the term "human." Likewise, Butler claims in Undoing Gender that her project necessarily begins and ends with "the human" (Butler 2004, 17). Butler's recent work explicitly belongs to what she calls a "post-Hegelian politics of recognition," which comprises an effort to destabilize and expand the designation of humanity in response to implicitly socially sanctioned violence against unrecognizable others (for example, Butler 2005). Grosz consistently exhibits suspicion, however, of any discourse of the human. Although Nietzsche is often invoked to support her emphasis upon the inhuman, her motivation is at least equally inspired by Irigaray's critique of the univocal and phallocentric logic of Western thought. When she defends her preference for a language of forces rather than subjects, she notes that feminists are likely to consider an idiom of force, power, and action to be masculine and patriarchal. "But this maneuver of identifying force with the masculine is already to humanize force (which in effect is to masculinize it, in a phallocentric logos), to anthropomorphize it and to refuse to see its role not as the effect but as the condition of subjectivity and subjective will" (Grosz 2005, 187). Thus, in this parenthetical identification of humanization with masculinization, one can detect her motivation for the language of force as proper to a politics of imperceptibility. Because, for Grosz, any and all humanization and anthropomorphism falls into a phallocentric economy of the same, she rejects the possibility of expanding and stretching the category of the human to include its excluded others. Although many feminists affirm that "the human" is always already masculine, most do not see any alternative to an appeal to this particular universal, especially if they are writing something like programmatic political theory. Yet Grosz remains in a programmatic hortatory mode where, instead of modifying and endeavoring genuinely to universalize a single overarching term, she promotes a turn to the inhuman, to the multiplicity and disunity of natural and bodily forces, to the non-discursive, non-representable terrain of actions, affects, and becomings. 
Although Grosz does not condemn any and all humanist political theories tout court, she claims that feminist and anti-racist struggle is starved for new languages, new concepts, and new problems (Grosz 2002, 463). Perhaps only a radical attempt to exit the regime of recognition and its corresponding desire for visibility and intersubjective affirmation can yield a new horizon for thought and action?

\section{THINKING BEYOND THE (Hu)MAN}

One of the distinctive aspects of Grosz's counter-proposal it that she seems to call for a more primitive and naturalistic language rather than a more sophisticated, more adequate conceptualization of our increasingly diverse world. She invokes Nietzsche's familiar critique of the subject as a "productive and activating fiction" (Grosz 2002, 466) and invites us to think instead about forces, energies, and acts below and above the level of the human. Since most feminists who appropriate the Hegelian intersubjective model are nevertheless unable to accept it in its entirety, she reasons that they ought "to begin with different working assumptions," assumptions that do not depend upon a particular response from another, a receptive audience, or even the articulate demands of conscious agents. As Linda Alcoff points out, many women and racial minorities do not experience their identities and social positions as oppressive, damaging, or painful (Alcoff 2005). The politics of recognition speaks especially to those who suffer misrecognition and felt psychological oppression, what Taylor refers to as "crippling self-hatred." Given the diversity of psychologies and lived experiences of social identities, might there be an important place for a politics grounded in a set of positive demands and aspirations rather than the negative exigencies of redress, reparation, and restitution? Perhaps we might be well served to galvanize political action around an effort to expand, enhance, and proliferate corporeal desires, pleasures, and activities? Although it would likely be cruel and foolish to abandon political efforts in the realm of representation that aim to repair the effects of genocide, slavery, and colonialism, a commitment to resist the gravest forms of injustice need not entail the eclipse of other creative and affirmative collective endeavors. Moreover, experiments in political thinking and practice might supplement rather than threaten ongoing efforts to recover from violence and to engender better ways of living in common.

Grosz makes an urgent call for "new intellectual resources" to address domination (Grosz 2002, 463; emphasis in original). Toward that end, she suggests that "[s]ubjects can be conceived as modes of action and passion, a surface of catalytic events, events which subjects do not control but participate in, which produce what history and thus what identity subjects may have" (468). Rather than a "psychical interiority inhabited by the specter of the other," she advocates a perspective in which "what marks the subject as such is its capacity to act and be acted upon, to do rather than to be, to act rather than 
to identify" (466). Thus, she endeavors to address the same phenomenaidentity and social subjectivity-that preoccupy many feminists and antiracists today, but in an alternative idiom. Grosz claims that we are confronted with "a theoretical choice" between what is ultimately a humanist, however deconstructed, "theory of the subject" and what she calls an inhuman "theory of impersonal," natural forces. Although she attributes this alternative language and theoretical lens to Nietzsche, they might equally be predicated of Spinoza. ${ }^{3}$ Spinoza's thoroughgoing challenge to anthropocentric thinking can supplement the alternative, impersonal angle she proposes. Moreover, compared with Nietzsche's philosophy, Spinoza's thought exhibits less suspicion toward collective efforts to live and think joyfully and powerfully together, and arguably has greater potential for the elaboration of a positive, feminist agenda. Indeed, a number of feminists have recognized Spinoza's philosophy as a rich resource (for example, Gatens 1996; Gatens and Lloyd 1999; Braidotti 2002). Nietzsche surely alerts modern subjects to our problematic assumptions, habits, and investments with more rhetorical force than perhaps any other philosopher. I would like to suggest, however, that Spinoza opens up still further avenues for the practice of a politics of imperceptibility.

In support of Grosz's program as I interpret it, Spinoza's philosophy offers a rubric of analysis that denies the radical uniqueness of human being with respect to the rest of nature. Although Spinoza was writing well before Hegelian theories of recognition and the politics entailed by it, his thinking might be understood to resist a politics predicated on apprehending the unique interiority of fellow subjects. Although Spinoza shares Hobbes's view that human ambition and desire for esteem must be presupposed in the successful organization of a state, this does not mean that collective well-being is best served by aiming to satisfy such desires. That is, Spinoza's political writings, far from according priority to individual or group recognition, provide structural means to reorient such desires that might be educated and fulfilled in alternative ways, according to the affective therapy described in the Ethics. ${ }^{4}$ Indeed, the appendix to the first part of the Ethics identifies the need to be preferred and loved as an individual by God and one's fellows as a source of both personal misery and human conflict. Similarly, the preface to the Theological-Political Treatise criticizes religious groups for making themselves recognizable primarily through superficial differences from other sects rather than on the basis of a genuinely admirable strength of spirit or a capacious ability to love other human beings (Spinoza 1998, 4). In other words, even as Spinoza's psychology, in the Ethics as well as in the political writings, stresses a desire to be enjoyed and admired by others, this psychological principle does not necessarily lead to either a neo-Kantian or neo-Hegelian emphasis on the respect and esteem owed to social subjects as central to a just political order. On the contrary, in the best-case scenario, ambitio, the desire to please and be esteemed by fellow human beings (E IIlp29s), finds higher expression in the gloria of a non-reciprocal intellectual love of God (E Vp19, Vp36s). While the 
Ethics moves toward an impersonal identification with God, nature, and human community, the political writings, in complementary but different ways, likewise aim to redirect rather than satisfy interpersonal passions for esteem.

A full analysis of the vicissitudes of the desire for glory and esteem in Spinoza requires a separate treatment, but for now, I will suggest that the remedy for the desire for recognition is not the other's perception and affirmation of one's claims and projects, and it is certainly not the fulfillment of the desire to be desired. Rather, the remedy for the affect of ambitio must include the displacement of the drive for that special kind of respect owed to one's humanity. Even if the desire to be esteemed and to enjoy oneself as the cause of the pleasure of fellow humans animates many of our actions, it cannot become a force of freedom as long as it depends upon being seen as an absolute special genre of being, elevated out of nature by virtue of one's rationality, consciousness, unconditioned will, or anything else. The remedy for the affect of ambitio or typical gloria involves the indissociability of humanity from the rest of nature. Paradoxically perhaps, my contention is that the self-love and the production of collective power and pleasure at which the desire for recognition aims require a non-humanist theory of agency and desire.

Spinoza's distance from humanism is probably best captured by his remarks in the preface to part III of the Ethics, dedicated to an account of the "origin and nature of the affects." He distinguishes his theory from those who treat "man" as though he is "outside Nature," as if the human realm is a "dominion within a dominion ... that disturbs, rather than follows, the order of Nature." What has been called his "anti-humanism," of course, is not an opposition to human happiness or freedom, which is no less the preoccupation of his philosophy, but a rejection of the idea that there are special laws that belong to human existence alone, in any of its manifestations. The laws and powers that determine human existence are no different from the laws and powers that determine and express nature as a whole. Thus, Spinoza affirms that "the way of understanding the nature of anything, of whatever kind, must ... be the same, namely, through the universal rules of Nature." Since one learns about all natural phenomena according to the same method, he ends the preface to part III with the famous remark, "I shall consider human actions and appetites just as if it were a question of lines, planes, and bodies." ${ }^{16}$ Thus his study of emotions or affects, just like his study of minds and bodies, applies to any and all natural beings, "all of which, though in different degrees, are nevertheless animate" (IIp13s).

Human happiness, in short, rests upon ceasing to see ourselves as special, unique, or exceptional with regard to the tendencies and character of natural existence. In contrast to the Hegelian tradition and the progressive spiritualization and socialization of the natural world, freedom and happiness on Spinoza's model entail becoming as attentive as possible to one's particular being as a tiny part of nature whose character one both constitutes and shares. This general view motivates his well-known critique of free will and subjective interiority 
begun in the appendix to Part I of the Ethics. I would like to suggest that what has been called Spinoza's anti-humanism is motivated precisely by a desire to mitigate misanthropy. Throughout his writings, Spinoza notes that philosophers and moralists tend to deride and ridicule human nature in the face of violence and folly. Alternatively, they create utopian political theories that ultimately serve the same function-they mock humans as they really are by imagining them as one would prefer them to be (Spinoza 2000, 33). He aims, in contrast, to understand human behavior and tragedy just as one would study the properties and turbulent dynamics of the atmosphere.

As I interpret him, fully philanthropic motivations animate what some have decried as Spinoza's dispassionate inhumanity (for example, Alquié 1981; Nussbaum 2001). Spinoza's polemic against privileging human experience and uniqueness is meant to enable a more genuine self-affirmation and understanding. One can love oneself and other similar beings only by getting over oneself, or relinquishing a cherished image of humanity and personhood. At the end of Ethics II, for example, Spinoza notes that his argument against the autonomy of the human will "contributes to social life, insofar as it teaches us to hate no one, to disesteem no one, to mock no one, to be angry at no one, to envy no one" (p49s). Likewise, in Part V, Spinoza affirms that if we understand "that men, like other things, act from the necessity of nature," then we will not be governed by our hatred of them (p10s). The refusal to elevate humans out of nature, according them a special status by virtue of their rationality, interiority, or freedom of will, allows us to respond differently to the many destructive things that people do. The affective therapy of the Ethics aims to enable us to act based on joy and understanding, rather than fear, anxiety, hatred, envy, or pain. By understanding ourselves as natural beings subject to the determinations of our environment and constituent relationships, like any other thing in nature, we may also be able to hate ourselves less for our weaknesses or failures. Likewise, the acknowledgment that one's good fortune may just be a fortuitous arrangement of forces may render one less prone to take solace in critical distance from human folly. Hopefully, the understanding of the causal unity of nature can prompt us to grasp our vulnerability to the affects and activities of proximate beings, and thus spur us to action rather than the typical philosophical stances of contemplation or condemnation.

In a similar vein, in an interview, Grosz distinguishes herself from Judith Butler, who has probably undertaken one of the most profound radicalizations of social construction, thoroughly denaturalizing any notion of sex or gender. Grosz notes that "denaturalizing is important. But it is not my project. We have, by now, been denaturalized as much as we need to be. What I'm much more interested in [is a] sort of renaturalizing that has been taken away, redynamizing a certain kind of nature" (Found Objects Collective 2007, 5). It is this effort to infuse our human perceptions, experiences, and concepts with an appreciation of their production within and as an a-centric force field of powers and counter-powers indifferent to human flourishing that Spinoza and 
Grosz share. It is my suggestion that the project of renaturalization comprises an alternative response to the "crippling self-hatred" that is the object of a politics of recognition. Rather than seeking the affirmation of one's humanity by other social subjects, or insisting upon an affirming self-representation within the social imaginary, one might strive to know oneself and others as singular instantiations of the infinite power of nature.

What would it mean politically, however, to affirm one's natural rather than human being? What kind of political practice follows from the renaturalization of humanity? One of the virtues of the politics of recognition is its insistence that we become who we are only by virtue of others (intersubjectively). Moreover, it contends that justice issues from a complex social dynamic that includes a robust affective dimension in excess of individual psychologies. As I interpret Spinoza, self-knowledge and the appreciation of one's power as immanent to nature are likewise collective accomplishments. A Spinozan politics necessarily entails the collaboration of others, but it is important to consider those others to include more than human beings, and to consider the causes and effects of our collective interaction in excess of consciousness or intersubjectivity. Although Spinoza certainly privileges human interactionas he affirms that "to man ... there is nothing more useful than man"- the power to think and act depends upon many other beings, human and nonhuman. Broadening one's frame of reference, apprehending political power and individual agency as something that involves more than social relations, might mitigate many sad passions that animate a culture of justice as retribution, recrimination, and reparation. Depriving humanity of its special status as part of a project of loving and knowing ourselves and the non-human beings on whom we depend is arguably of increasing importance in an epoch that threatens environmental catastrophe. I have yet to make any suggestions, however, about what kind of political practices and institutions a politics of imperceptibility might entail. I will conclude with some thoughts toward that end.

\section{A POLITICS OF IMPERCEPTIBILITY}

The politics of imperceptibility, as I understand Grosz, serves as a critique of thinking exclusively in terms of human representations, while it proposes a project of an emancipatory renaturalization through an appreciation of material forces that are indifferent to human conceptualizations even as they comprise them. As Grosz is surely aware, Spinoza offers her project one of the most rigorous and uncompromising critiques of human transcendence. Spinoza's philanthropic non-humanism likewise serves as a kind of foundation for the Deleuzian resistance to philosophies and politics that privilege representation and identification. When Deleuze and Guattari invite us to consider becoming-imperceptible, they are not advocating a retreat from perception absolutely, as if that were possible. Perception in itself is not 
necessarily problematic, and it is clear in Spinoza's philosophy that perception names something that far exceeds our consciousness. For example, Spinoza contends that "nothing can happen in that body which is not perceived by the mind" that is an idea of that body (E IIp12), and yet "the human mind does not know the human body" (E IIp19s), and usually only marvels at what it can do (E IIlp2s). For Spinoza, perception is something that happens in nature rather than being a uniquely human phenomenon. In fact, human knowledge and imagination depend upon nature's power to perceive the events, activities, and passions that follow necessarily from modal existence, while individual thinking powers have only very imperfect access to the encounters that affect their own bodies. Deleuze and Guattari seem to target not the perceptive power of nature itself, but rather the dominant regime of perception, the social imaginary that filters, contours, and categorizes beings into intelligible entities. Their affirmation of becoming-imperceptible suggests that the hegemonic socio-symbolic order always needs to be resisted and challenged, lest we lose access to the flows and relationships that support or inhibit our actions and passions.

Children and the insane largely figure as Deleuze's and Guattari's examples of becoming-animal on the way to becoming-imperceptible. The exemplary children do not perceive the world as cut up into atomistic parts. Rather, on their account, the children apprehend assemblages of proximate beings together producing effects, as when little Hans notices the horse-omnibusstreet. Those who cease to operate in terms of the hegemonic socio-symbolic order, who fail to use names appropriately, or who begin to imitate the affects of beasts or things other than human exhibit an affirmation of nature as replete with possibilities for relationships and becomings other than those prescribed by the dominant order. They do not become imperceptible absolutely; they are not in principle inaccessible to other bodies and minds. Rather, they fail to conform to the dominant social imaginary and travel a less manifest path, among the infinitely many, that comprise nature. If the examples in $A$ Thousand Plateaus, however, are largely children, werewolves, and socially defined madmen, how does this translate into a politics of imperceptibility? Moreover, what is especially feminist or anti-racist about the politics that such meditations inspire?

Grosz's schema offers inspiration and redirection without a great deal of positive guidance. A politics of imperceptibility, above all, entails considering the subject in terms of vital forces. In her words, "Rethinking the concept of the subject in terms of force means profound transformations in all related concepts—of objects, of the social, of actions and agency" (Grosz 2002, 469). In her recent writings, Grosz openly promotes an increasingly "abstract" feminist theory, one that involves an overhaul of the most fundamental ontological categories. Grosz's work has become increasingly autonomous from specific problems and issues that traditionally preoccupy feminist and antiracist thought. For example, it does not often treat particular institutions of 
oppression, but rather meditates upon the character of time, space, and force. Her work has given rise to a style of thinking that is not confined to answering to the most manifest exigencies in the lives of women or racialized minorities. Such a style of thinking risks appearing to be non-feminist, or at least detached from lived experiences of oppression. Yet the circumscription of feminist theory to women's issues domesticates and restrains feminist thought. It treats feminist thought as an application of philosophy, rather than as a proper and comprehensive philosophical effort. Nevertheless, Grosz's intervention into the debate surrounding the politics of recognition reveals that her creative style of thinking contains certain political prescriptions.

Beyond what sometimes appears to be a detachment from particular exigencies in the lives of women, Grosz's thought shares with Spinoza's a kind of irony. Grosz explicitly advocates greater abstraction in feminist theory, and, similarly, Spinoza's thought strikes critics as well as admirers as hyper-rational and distant from life experience. While my treatment of Spinoza engages his entire corpus as practical philosophy, both Spinoza and Grosz advocate, above all, a radical transformation of thinking. While both present a picture of nature as a realm of agonistic forces indifferent to human well-being, their very projects promote and exemplify intellectual efforts that may seem entirely distinct in character from an arena of competition among bodies struggling to survive and thrive. While I only begin to develop such a claim in what follows, Spinoza's "parallelism" of mind and body supports a portrait of ideas themselves as forces, as desiring powers in nature, striving to prolong and enhance their existence. ${ }^{7}$ The life of ideas is not different in kind from the life of bodies ( $\mathrm{E}$ IIp7). On such an interpretation, one should understand both Spinoza's and Grosz's intellectual interventions into the discourses of their day as energetic, forceful activities that aim both to combat and suppress certain ideas as well as to enjoin others to form a counter-mode of thinking and being. Moreover, while agonism belongs to this process, being a force in nature does not entail only opposition to others. Forces both thrive and suffer by virtue of their relationships to ambient forces. The arguments contained in their philosophies represent not only some measure of prescription for alternative ways of thinking and living, and thus constitute efforts to impose themselves on other modes of thinking, but they are also lived enactments of those very alternatives. Their efforts to think differently are evidence that they have already enjoyed some fortuitous encounters with other minds and bodies and marshaled the power to know themselves and live in their worlds according to different norms. One should understand Spinoza's Ethics, a treatise on the pleasure and power of understanding, as such a product and project of assembling forces to think, feel, live, and love oneself, like any other thing, as a part of nature. Grosz's ideas are both nourished and constrained by a history of suffering and acting among feminist and anti-racist ideas, since these traditions of thought comprise a milieu of ideal forces in which her ideas exist and act. Her thought both produces and is produced by this ideal environment, 
and her interventions both instantiate and constitute a transformation of this force field of ideas (which always has a concomitant life in the realm of bodies).

While only the actual lived experience of thinking and acting with others will reveal what such alternative theories might yield, Grosz promotes a politics of imperceptibility as an alternative to feminine and racialized subjects beseeching masculine, colonial, or other dominant subjects to meet their needs, recognize them, and validate them. Rather, her alternative consists in an effort "to become more mobile, more fluid and transformable." Instead of an effort to be valued, feminism becomes a "struggle to mobilize and transform the position of women, the alignment of forces that constitute that 'identity' and 'position,' that stratification that stabilizes itself as a place and an identity" (Grosz 2002, 471). Finally, she advocates the politics of imperceptibility as that which does not belong to anyone, that leaves its "traces and effects" everywhere, but is known, or perhaps only felt, retrospectively as increased mobility, as enabling and surprising encounters and energies that make womanhood or raced subjectivity other than it was. How, then, might one endeavor to engage in a politics of imperceptibility? For those who are attracted to her solicitation, how does one galvanize such imperceptible destabilization?

Like the plateau from which Grosz takes her inspiration, one might wonder whether becomings-animal and -imperceptible just happen, independent of any subjective effort, or whether one may undertake such becomings as a project. Certainly, this critique of the subject does not allow for a teleological plan to be drawn up and executed according to the transparent wills of human actors. Yet Grosz does not advocate simply an attunement to becomingimperceptible, but precisely a politics of imperceptibility. I would like to suggest that Spinoza's philosophy might offer a way to consider political practice in terms of the imperceptible forces that condition and issue from our affective engagements with human and non-human beings. Thus, one can understand a politics of imperceptibility as a politics that produces different indices of effecrivity, which will likely give rise to alternative practices, without offering a distinctive blueprint for political organization. In contrast to a recognitive measure of justice, political practice might be analyzed and assessed in terms of the corporeal capacities, energies, and pleasures to which it gives rise. Concomitantly, the production of ideas through political engagement will not be examined in terms of their power to engender true representations, subjective understanding, or transparency among citizens, or between citizens and the state. Rather, the index of successful mental assemblages will be the ability of collectivities to produce potent and enabling ideas. ${ }^{8}$

As an example, consider Spinoza's frequent counsel for the organization of large deliberative assemblies. The insistence upon collective deliberation productive of rationality seems to link Spinoza comfortably to today's neoHegelians. Yet we might understand and pursue this very same practice from 
the orientation of a politics of imperceptibility. In the Theological-Political Treatise, Spinoza advocates democracy on the basis that a large number of thinking powers assembled together generate better ideas: "in a democracy there is less danger of a government behaving unreasonably, for it is practically impossible for the majority of a single assembly, if it is of some size, to agree on the same piece of folly" (Spinoza 1998, 178). Even more forcefully, he claims in the Political Treatise that collective discussion brings into being ideas that could never emerge from the meditations of a solitary leader, however sage.

[W] hen all decisions are made by a few men who have only themselves to please, freedom and the common good are lost. The fact is that men's wits are too obtuse to get straight to the heart of every question, but by discussing, listening to others, and debating, their wits are sharpened, and by exploring every avenue they eventually discover what they are seeking, something that meets with general approval and that no one had previously thought of. (Spinoza 2000, 126; my emphasis)

Spinoza advocates deliberation as a productive process generative of ideas that might best guide a collectivity in accordance with its own power of perseverance and flourishing. He recommends large assemblies, I would like to suggest, because ideas, like bodies, need to be connected and their strivings joined to one another by actual proximity. ${ }^{9}$ The forces and energies need to interact and encounter one another in excess of the particular imaginings, desires, and volitions of the individuals involved.

Part IV of the Ethics has as its first proposition: "nothing positive which a false idea has is removed by the presence of the true insofar as it is true." Truth has no added power by virtue of its veracity. A genuine apprehension of the rationality, worth, and value of one's fellow citizens as they truly are will not endure, will not have social force, simply by being accurate. In order to change the pernicious effects of distorted and damaging representations, therefore, it is not enough to persuade others of their falsity, or to disclose publicly the truth of one's interiority, if that were possible. Ideas, representations, and perceptions have power insofar as they condition and flow from many thinking powers independent of their will. In order for such ideas to take hold of subjectivities, determine their actions and passions, bodies and minds must enter into open-ended engagement and undergo what emerges.

Because true ideas cannot become powerful simply by virtue of being true, but must mobilize and connect with a great many other similar ideas, many thinking powers must pool their efforts to bring into being and sustain ideas that express vitality and flourishing. Ideas, like bodies, are forces. Thus, no matter how true, they will die without many others to sustain them. The fragility of any particular idea speaks to the difficulty not only of arriving at enabling ideas, but of sustaining and strengthening them. In other words, even 
the realm of politics that is most often examined in terms of intersubjectivity, recognition, and communicative action as the dialogical generation of rationality can fruitfully be considered a project of power, a theater of productive, nourishing, and agonistic forces. Such an effort to think differently about our practices may not (and perhaps cannot) displace intersubjective struggles for recognition. Yet it may open up new avenues for practice and new criteria for effective political activity. Considering subjects in terms of the forces and energies that condition and flow from them might lead us to revise what it means to think and live well.

We might take an analogous perspective on the traditional feminist practice of consciousness-raising. Such a practice might seem to have little place in a theory that de-privileges consciousness and intersubjectively derived truth. Indeed, as it is conventionally understood, consciousness-raising coincides very well with the commitments of a politics of recognition to mitigate self-loathing. First, as Catharine MacKinnon describes in her classic piece, like the politics of recognition, consciousness-raising is an intersubjective practice that engenders a positive identity-formation. She cites Sheila Rowbotham approvingly, "In order to discover its own identity as distinct from that of the oppressor, [an oppressed group] has to become visible to itself" (Rowborham 1973, 27; cited in MacKinnon 1989, 84). Mackinnon associates feminist theory generally and consciousness-raising in particular with striving to become visible to oneself and others through a process of mutual self-clarification and group identification. Group identification engenders solidarity and thereby establishes new sources of self-esteem. Women are able to find validation in other women who can recognize their contributions to society as meaningful, necessary, and world-sustaining (compare Honneth 1996). The method of discussing women's day-to-day lived experience reveals patriarchy-a systematic form of "identity invalidation" for women-to be the source of their feelings of inadequacy (Mackinnon 1989, 91, 93). The virtues of this feminist technique are precisely those identified as necessary by the politics of recognition as it is formulated by Honneth and Taylor. That is, consciousness-raising serves to attenuate self-loathing, produce solidarity and self-esteem, and generate a less distorted and more accurate apprehension of oneself and other oppressed women. It is a practice that aims to see through patriarchal social conventions and undo the psychic mutilation they have wrought. Thus, it is unsurprising that "[t]he analysis that the personal is the political came out of consciousness raising" (MacKinnon 1989, 95).

Grosz's plea for an impersonal politics of bodies and natural forces would seem to be utterly alien to something like consciousness-raising; indeed, it is alien to such a practice as it is traditionally understood. I imagine Grosz would share many of the suspicions that Wendy Brown articulates with respect to a project predicated upon disclosing the "hidden truth' of women's experience" (Brown 1995, 42). Indeed, an impersonal politics inspired by Nietzsche would have little more than contempt for a project of instituting a unitary female 
experience, armed with Truth against patriarchy, a regime of distorting lies. Although any feminist politics organized around a pursuit of the truth of woman's oppression would seem untenable among many of today's feminist and anti-racist theorists, I would like to suggest that a practice similar to consciousness-raising could be approached from an impersonal perspective. An assemblage of feminized beings, or those with a desire to render their gendered social location less static, might be reimagined and reoriented as a collective production of powers, linkages, and transformations. Assembling to think and act with others who desire to live, feel, and experience themselves otherwise might find a place as an experimental process grounded in little more than the yearning to generate a counter-power, a new arrangement of corporeal forces, and alternative sources of pleasure and agency. In contrast to the endeavor to recognize one another as sharing analogous experiences and interchangeable relationships to the social structure, and in contrast to an effort to recognize "who we are," a politics of impersonality might focus on what we desire (Brown 1995, 75). Following Grosz, Brown, and Spinoza, impersonal politics can take its point of departure from the desire to enhance one's pleasure and power through encounters with other bodies. It is an affective politics that privileges enabling relationships, wherever they may be found, rather than particular humans or institutions.

As I imagine it, an impersonal politics does not necessarily invalidate traditional feminist or anti-racist practices of resistance, even as it re-imagines and approaches them with new criteria of success. From this point of view, one aims not (only) to be understood or valued by one's fellows, but rather to feel stronger, to discover affinities with other vital forces, and to be open to alternative futures. A politics of imperceptibility affirms that human existence is within and not above nature. We depend upon and affect innumerable forces, human and non-human. The measure of our agency that depends upon other's perceptions of us and our self-understandings may be significant, but it is hardly the totality of our power and freedom. Moreover, intense attention directed at our need to be seen as who we really are may be self-defeating. As many note, our identities are constantly being revised, reinterpreted, and experienced differently in response to new encounters. Likewise, a narrow focus on our negative experiences and those who have harmed us may foreclose other sources of power and pleasure. Spinoza advocates an affective therapy in which we find our agency in as much of natural existence as possible. He emphasizes that acting effectively and living well is above all a matter of relations of power and force among singular desires. Although Spinoza himself exhibited little concern for women, a feminist politics of imperceptibility does not need him to recognize its validity. A feminist politics of imperceptibility simply siphons enabling energy and power wherever it happens to find it. It infects and enjoins whichever beings and forces might aid in the construction of a joyful insurgency against patriarchy, misanthropy, and, yes, "crippling selfhatred." 


\section{NOTES}

I would like to express my gratitude to the following sources of support: the Fonds québecois de recherche sur la societé et la culture for funding a research project on Spinoza and feminism; the comments and criticism of this paper offered at the annual meetings of the International Symposium for Phenomenology (July 2007) and the Society for Phenomenology and Existential Philosophy (November 2007); the feedback of an anonymous reviewer for Hypatia; and, as always, W. Roberts.

1. The proposal by Cornell and Murphy demonstrates the difficulty Markell indicates. How is the state to confer recognition upon identities subject to constant revaluation and recreation? Although they suggest that the state guarantees "the psychic and moral space" necessary for such self-recreation, they still insist that the state recognize individuals and groups as bearers of identities, albeit shifting and provisional ones. "Recognition" comes to be an awkward term for whatever state policies might promote such fluid processes of identification.

2. Both Taylor $(1992,26)$ and Honneth $(1996,121)$ insist on an ideal of recognition that removes distortion.

3. Given that Grosz's Nietzsche is mediated by Deleuze, who finds very similar strains of chought in Spinoza, it is not a big leap from one to the other. Moreover, the precise language of acting and being acted upon is closer to Spinoza's, although he more often discusses the body as what "affects and is affected" by others.

4. Sharp (2005) treats one of the structural means in detail.

5. I will proceed to cite Spinoza parenthetically in the body of the paper with the standard notation, using Edwin Curley's edition and translation (Spinoza 1985). Citations refer to the part (= Roman numeral), proposition $(=p)$, demonstration $(=d)$, scholium $(=s)$, corollary $(=c)$, appendix $(=\mathrm{app})$, preface $(=$ pref $)$, and definition $(=$ def $)$. (2010).

6. For an analysis of the function of the mathematical examples in the Ethics, see Sharp

7. I develop this interpretation of Spinoza's doctrine of ideas in Sharp (2007).

8. In the next three paragraphs, I borrow and reframe an account of the ideal assemblage of collective deliberation from Sharp (2007).

9. Spinoza's advocacy of large deliberative assemblies certainly does not exhaust his political philosophy, which I treat only selectively throughour this paper, relying more heavily upon the Ethics. His political philosophy comprises an exceedingly complex treatment of the uneasy relationship between passions and actions, irrationality and rationality, in the collective body. Although 1 find that most interpretations exaggerate the difference between the ethical and political projects, especially with respect to the putative pessimism Spinoza evinces about the potential for mass empowerment and collective activity, I select the example of deliberation by virtue of its proximity to the politics of recognition. As I mention in the introduction, my argument here is not that Spinoza's political theory is in every way comparible with, or identical to, Grosz's politics of imperceptibility. Rather, I am making the more modest claim that Grosz's vision can find resources in Spinoza's philosophy as a whole and that Spinoza's thought fills out her suggestive remarks about a politics of imperceptibility.

\section{REFERENCES}

Alcoff, Linda. 2005. Visible identities: Race, gender, and the self. Oxford, N.Y.: Oxford University Press.

Alquié, Ferdinand. 1981. Le rationalisme de Spinoza. Paris: Presses universitaires de France.

Braidotti, Rosi. 2002. Metamorphoses: Toward a materialist theory of becoming. Cambridge, UK: Polity Press. 
Brown, Wendy. 1995. States of injury: Power and freedom in late modemity. Princeton: Princeton University Press.

Butler, Judith. 2004. Undoing gender. London: Routledge.

- 2005. Giving an account of oneself. New York: Fordham University Press.

Cornell, Drucilla, and Sara Murphy. 2002. Anti-racism, multiculturalism, and an ethics of identification. Philosophy and Social Criticism 28 (4): 419-49.

Deleuze, Gilles, and Felix Guattari. 1987. A thousand plateaus. Trans. B. Massumi. Minneapolis: University of Minnesota Press.

Found Objects Collective. 2007. An interview with Elizabeth Grosz, http://web.gc.cuny.edu/csctw/ found_object/text/grosz.htm (accessed December 14, 2007).

Fraser, Nancy. 1995. From redistribution to recognition? Dilemmas of justice in a "post-socialist" age. New Left Review 212:68-93.

Frazer, Elizabeth, and Nicola Lacey. 1993. The politics of community: A feminist critique of the liberalcommunitarian debate. London: Routledge.

Gatens, Moira. 1996. Imaginary bodies: Ethics, power, and corporeality. London: Routledge.

Gatens, Moira, and Genevieve Lloyd. 1999. Collective imaginings: Spinoza, past and present. London: Routledge.

Grosz, Elizabeth. 1993. A thousand tiny sexes: Feminism and rhizomatics. Topoi: An Intemational Review of Philosophy 12 (2): 167-79.

-2002. A politics of imperceptibility: A response to "anti-racism, multiculturalism and the ethics of identification". Philosophy and Social Criticism 28 (4): 463-72.

- 2005. Time travels: Feminism, nature, power. Durham, N.C.: Duke University Press.

Honneth, Axel. 1996. The struggle for recognition: The moral grammar of social conflicts. Cambridge, Mass.: MIT Press.

Honneth, Axel, and Nancy Fraser. 2003. Redistribution or recognition? A political-philosophical exchange. London: Verso.

Kittay, Eva. 1998. Love's labor: Essays on women, equality, and dependency. London: Routledge.

MacKinnon, Catharine A. 1989. Toward a feminist theory of the state. Cambridge, Mass.: Harvard University Press.

Markell, Patchen. 2000. The recognition of politics: A comment on Emcke and Tully. Constellations 7 (4): 496-506.

2003. Bound by recognition. Princeton: Princeton University Press.

Nussbaum, Martha. 2001. Upheavals of thought. Cambridge: Cambridge University Press.

Oliver, Kelly. 2001. Witnessing: beyond recognition. Minneapolis: University of Minnesota Press.

Rowbotham, Sheila. 1973. Woman's consciousness, man's world. Harmondsworth, UK: Penguin.

Sharp, Hasana. 2005. Feeling justice: The reorientation of possessive desire in Spinoza. Intermational Studies in Philosophy 37 (2): 113-30.

- 2007. The force of ideas in Spinoza. Political Theory 35 (6): 732-55.

2010 (forthcoming). Nemo non videt: Intuitive knowledge and the question of Spinoza's elitism. In Montreal studies in the history of philosophy, Vol. 1: The rationalists: Between tradition and revolution, ed. C. Fraenkel, D. Perinetti, and J.E.H. Smith. Dordrecht: Springer Press.

Spinoza, Benedictus de. 1985. The collected works of Spinoza, Vol. 1. Trans. E. Curley. Princeton: Princeton University Press.

- 1998. Theological-political treatise. Trans. S. Shirley. Indianapolis, Ind.: Hackett. 2000. Political treatise. Trans. S. Shirley. Indianapolis, Ind.: Hackett.

Taylor, Charles. 1992. The politics of recognition. In Multiculturalism and the politics of recognition, ed. Amy Guttman. Princeton: Princeton University Press, pp. 25-74. 


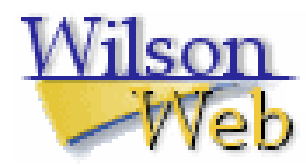

\section{COPYRIGHT INFORMATION}

TITLE: The Impersonal Is Political: Spinoza and a Feminist Politics of Imperceptibility

SOURCE: Hypatia 24 no4 Fall 2009

The magazine publisher is the copyright holder of this article and it is reproduced with permission. Further reproduction of this article in violation of the copyright is prohibited. 